\title{
VERSITA
}

\section{The 'Underclass' Debate - A Discourse that Maligns People Living in Poverty}

\author{
Hans-Peter Michels ${ }^{1}{ }^{*}$ \\ ${ }^{1}$ Brandenburgische Technische Universität Cottbus-Senftenberg (BTU CS), Fakultät für Wirtschafts- und Sozialwissenschaften, \\ Musikpädagogik, 47 Lipezker Str., 03048 Cottbus, Germany
}

KEYWORDS

Underclass

Neoliberal ideological transformation

Social inequality

Poverty

Charles Murray

Stigmatisation of the

poor

\begin{abstract}
The concept of an 'underclass' originates in the United States and is wide-spread in political and social science discourse today. Its power is most visible in discussions about deep cuts to social safety nets. The foundation of this discourse is the assigning of negative character traits and behaviours to poor people. This promotes the claim that they have brought negative consequences upon themselves and furthers the idea that poor people are personally responsible for their poverty.

Discussion about an 'underclass' must be understood in the larger context of a comprehensive neoliberal ideological transformation, or 'Newspeak'. Newspeak is implicitly based on the schema of a game in which everyone has the same chances, but which inevitably results in winners and losers.
\end{abstract}

\section{Introduction}

The concept of an underclass has existed in political and academic discussions about social inequality since the end of the 1960s. It is an attempt to replace class theory of all modes, including the work of Max Weber, Pitirim Sorokin, John Goldthorpe, Pierre Bourdieu and Marxist theorists. The underclass discourse has been one of the most influential ideological transformations of the last few decades, and has succeeded in upending the

\footnotetext{
* Contact address: hp.michels@web.de (H.-P. Michels)
} 
previously established definitions of 'classes' (see Projekt Ideologie Theorie 1979).

Since the middle of the 1970s, this discourse has been propagated with the ongoing support of the largely conservative think tanks in the USA. It has been disseminated particularly widely in Great Britain and in Germany. Terms and arguments from this discourse can no longer be ignored in current political and ideological conflicts.

The work of the French sociologists Pierre Bourdieu and Loic Wacquant is particularly helpful for understanding this switch in the understanding of the meaning of 'class' and associated terminology. According to them, 'underclass' is one of the words of the 'strange Newspeak' that is being spread world-wide by the 'partisans of the neoliberal revolution'. 'Newspeak' is a newly formed language or terminology whose terms tend to originate in US think tanks, academic disciplines, and in the media. They tend to be formulated generally and abstractly. Any concrete local-historical roots are almost entirely obscured. Instead, Newspeak terms are formulated to be universally applicable so that they can be used and furthered internationally. Often academics and journalists in Great Britain act as a sort of intermediary for this ideology ${ }^{1}$, filtering American thought and bringing it to continental Europe (Bourdieu and Wacquant 2001).

As I will show, a similar process has accompanied the conceptual foundation and distribution of the underclass concept. Although there have been country-specific adoptions of this terminology in Great Britain and Germany, the function of this discourse is universally the same: ideologically preparing for and/or accompanying the dismantling of social safety nets.

\footnotetext{
${ }^{1}$ This is possible because of historical, cultural and linguistic commonalities.
} 


\section{The twist of the term 'class'}

Gunnar Myrdal introduced the word 'underclass' as a scholarly term. Derived from the Swedish Underklass, Myrdal used the term to describe new phenomena in the advancing capitalist economy (see Kronauer 2010). He believed that social inequality was determined by socioeconomic and structural differences. He defined 'underclass' as a:

'class of unemployed, unemployables, and underemployed who are more and more hopelessly set apart from the nation at large and do not share in its life, its ambitions and its achievements' (Myrdal 1962: 10).

His analysis of the conditions that bring about the development of the underclass, however, was not given much attention: he believed that the development of productive forces in the most innovative capitalist economies led to the redundancy of work forces - and not only unskilled workers. On the political side, hardly any worthwhile compensatory provisions were made (for example reintegration measures for the un- and underemployed), and to some extent the precarious situation of this group was made even worse by cuts to social safety nets.

Eventually the term 'underclass' was taken over by the 'academics' and journalists who shaped the underclass discourse. The central argument of the discourse was formulated early on by Harvard University political scientist Edward C. Banfield, a political advisor to the Republican Presidents Nixon, Ford and Reagan, in his book The Unheavenly City Revisited (1974 [1968]). Breaking from the understanding of class theory that was at that point dominant in the social sciences, in which it was understood that membership in a class to be fundamentally based on social conditions, Banfield declared psychological and cultural characteristics to be the basic reason for belonging to a social class.

He differentiated a 'lower class culture' from the culture of the 'working class', 'middle class' and 'upper class' (Banfield 1974 [1968]: 54). He defined the 'lower class' by specific patterns of personality traits, 
attitudes, values and behaviour. This lowest 'class' of poor people ${ }^{2}$ had attitudes, values, and patterns of behaviour that allowed them to be clearly differentiated from other 'classes'.

In his definition of the attitudes and behavioural patterns of the 'lower class', Banfield highlighted the central significance of 'future-orientation'3. Those who belonged to this 'lower class' had a 'present-orientation'. They lived for the moment, gave in to desires immediately, and were interested in instant gratification. They had little self-discipline or determination. They lacked a plan for the future or a desire for education. They were characterized by impulsive behaviour, sometimes manifested through violence and vandalism. They were strongly inclined to sexual activities. They didn't feel responsible for their surroundings, which was why some neighbourhoods slowly fell into disrepair.

Banfield viewed any plans for government intervention or social programs to better the material living conditions or education of this group with scepticism, believing that members of the 'lower class' would not be able to profit from them because of their culture. Such measures could not result in a fast change, because the attitudes and behaviours of these people were so strongly ingrained. Instead he believed that the path to bettering their lives, and the most promising path towards the end of poverty overall was through a change in their work ethic and behavioural standards, flanked by police supervision and legal punishment.

Thus Banfield created a memorable policy concept, one that was easy to understand and that catered to people's wide-spread resentment of the poor and unemployed. It is therefore not surprising that other conservatives, especially political advisors (for example Moynihan, see Office of Policy

\footnotetext{
2 Here he meant the lowest group in a society that stayed in its position for a long time.

${ }^{3}$ Banfield compared the situations of poor Jews and Irish from 1885 until 1895 in the USA: 'Very likely, the present-orientation of the Irish and the future-orientation of the Jews had important indirect effects as well' (Banfield 1974: 68). Additionally, according to Banfield, because Jews at that point placed more emphasis on education they later tended to be more economically advanced than Irish immigrants.

${ }^{4}$ Daniel Patrick Moynihan contributed with his report on the 'War on Poverty' program of the Johnson administration in the 1960s.
} 
Planning and Research 1965) and journalists (for example Auletta 1981a, 1981b, 1981c) adopted this concept and promoted it widely.

Edward Banfield was then primarily responsible for leading cultural discourse on the 'underclass' in the USA. As has been shown, he defined 'classes' using attitudes, values, and behaviours, which broke away from the traditional definitions of class. Thus psychological factors were declared to be the most substantial identifier of 'class', as well as the most significant cause of the emergence of poverty.

\section{The moral foundation of the underclass concept}

Charles Murray provided an influential contribution to the debate with his 1984 book Losing Ground: American Social Policy, 1950-1980. He escalated the 'underclass' debate into the territory of morality. His arguments were used in order to force the neoliberal deconstruction of the social safety net and to strengthen penal law. His argument that the poverty-reduction programs that had been in place in America since the 1960s were themselves responsible for the rise in poverty proved especially influential.

In Losing Ground, Murray offered emotionally powerful hypothetical cases in an effort to prove that War on Poverty programs were counterproductive. For example, he wrote about the fictitious case of Harold and Phyllis, a young unmarried couple, who were expecting a child. According to Murray's reasoning, in 1960 this couple would have had to look for work as the only possible solution to their problems. After the reforms of the 1960s, the decision to rely on social programs would have been more rational than getting a job, because welfare would have led to a higher material quality of life. But according to Murray, this decision had only short term advantages:

'The first effect of the new rules was to make it profitable for the poor to behave in the short term in ways that were destructive in the long term. Their second effect was to mask these long-term losses to subsidize irretrievable mistakes. We tried to provide 
more for the poor and produced more poor instead' (Murray 1984: 9).

Murray argued that certain groups of poor people had quickly recognized that they could rely on the support of social welfare programs, which had disastrous consequences for self discipline, the motivation to work, and the desire for education. He blamed absolute dependence on welfare for the rising number of young unmarried black women with children born out of wedlock (he spoke of 'welfare mothers'). He wrote that unemployment and criminality had risen among young men ${ }^{5}$.

His argument was easy to grasp and found wide acceptance. It was based on a simple behavioural reinforcement model: political action on welfare, penal law, and education in the 1960s had set up false incentives. Within a short time, certain groups of poor people changed their behaviour in response. The short term nature of these effects negated sociological or economic explanations that the emergence of a new 'underclass' was the result of a societal transformation to a high tech economy. If that had been the case, then negative behavioural traits would not have developed so quickly among certain groups, but rather would have emerged in a delayed or long-term manner.

In Murray's 2012 book, Coming Apart: The State of White America, 1960 2010, he once again blames social programs that cause dependence and the problematic behaviour of the 'underclass' for the lasting problem of poverty - and indeed its deepening. He utterly refutes an economic explanation for inequality, and instead offers a one-sided or exclusive focus on cultural and behavioural factors to divide the 'upper' from the 'lower class'. (Moreover he concentrates exclusively on white Americans, where he argues that the difference between the 'classes' is determined culturally and thus not through a factor such as race.) The clear differences between the classes are founded on taste and cultural preferences.

\footnotetext{
${ }^{5}$ His description of young men made clear that he was referring to young black men, without ever explicitly stating it.
} 
In this book he once again uses fictitious case studies to illustrate his points. For example, he invents two imaginary neighbourhoods including Belmont, an 'upper class' neighbourhood, and Fishtown, which is inhabited by the 'underclass'. Thus he constructs a geographical segregation between rich and poor. According to him this is a grave problem, because those who belong to the 'new upper class' have lost contact with the members of the 'new underclass', which he believes must be restored.

In Murray's view the 'new upper class' is distinguished by high levels of education, dedication to their jobs and the value of a lasting marriage. They show strong community feeling and religiosity. In contrast, the poverty of members of the 'new underclass' is a result of their own moral decay. This white lower class is no longer religious, nor family oriented, and lacks both a work ethic and an education. They display none of the virtues on which America was founded, they have no sense of family, diligence, community feeling or religiosity.

Murray formulates his version of a psychological and moralizing view of social inequality with the extreme idea that morals declined first and the decline of American economic power followed in consequence. In his world, America still has a job for every person who wants to work.

Murray appeals with his book to members of the 'new upper class', whom he believes should teach members of the 'underclass' about marriage, family and self reliance, making it clear that they cannot rely on social help.

His arguments can be seen as an attempt to absolve American elites from any responsibility for the social deprivation and increasing extreme inequality in the country. Instead, he blames the so-called 'white trash' for the desolate position of the USA.

Thus these variations on the 'underclass' discourse in the USA upended the terminology of class. Instead of focusing on social conditions, this discourse focuses on negative characteristics and corrupt morals, in order to build the construct of a 'behavioural underclass' (Gans 1995). This describes the general definition of the concept of the underclass, as it arose 
in the USA. Because of its generality this conception of the underclass is easy to carry over to other societal and historical contexts.

By means of examples or vignettes about phenomena that are only superficially observed, the underclass argument can be adapted to suit the particulars of every country without having to change its underlying shape. In this sense, the underclass discourse is suited for global Newspeak. By simply adding examples adapted for societal and historical context, the idea of an underclass can gain a formidable plausibility. However, it cannot withstand closer analysis and observation, and most importantly it contradicts empirical findings (see for example Paugam 1994; Andreß 1998; Brenner 2006).

The examples from Murray's work cited above show some of the ways this discourse has been adapted to suit America. The majority of American authors illustrate their assertions with stories about teenage welfare mothers (see, for example, wide use of the 'welfare queen' caricature in the presidential campaign of Ronald Reagan) or young men who are criminal, arrogant and violent.

In this way a prototype of underclass membership was created that implicitly conveyed racist stereotypes without having to explicitly mention black people.

This discourse is still operating today. It was developed in the 1960s in the USA, and then became so influential in the 1980s that it enabled massive cuts to be made to governmental social services. A stereotype of poor people was created that labelled them as despicable individuals who tended towards criminality and promiscuity and who used the social safety net in order to live an extravagant lifestyle (see Gans 1995; Wacquant 1996, 2004).

\section{Antisocial youth as the core of the British underclass}

At the beginning of the 1990s, the concept of the stigmatized 'underclass' increasingly entered British public debate. Charles Murray propagated his extremely conservative concept in the UK as well, with his books The 
Emerging British Underclass in 1990 and Underclass: The Crisis Deepens in 1994. His main arguments about the situation in Great Britain were as follows: next to the poor from the 'working class' there existed a 'new rabble underclass'. These poor people were criminal, morally depraved, and not ready to work; they behaved antisocially and a large percentage of the young women had children out of wedlock. In Great Britain the underclass discourse was focused on young people, in much the same way that racist undertones shaped the discourse in the USA. Criminal young men and promiscuous young women were offered as prototypes for the British 'underclass'.

It is a construction of 'class' using age. 'Underclass' members were under 25 years old and were ascribed negative characteristics (see MacDonald 1997). A list of negative behaviours that correspond to the criteria for antisocial personality disorder 6 was supposed to identify offending young people and then allow for corrective measures (e.g. instilling a work ethic or offering certain sports) or an 'Anti Social Behaviour Order' which would mean compulsory or less harsh punitive measures.

In British politics the concept of 'antisocial behaviour' is used widely, and it serves as a foundation for corresponding political intervention. After the 2011 riots in cities including London, Liverpool and Manchester, Prime Minister David Cameron blamed criminal elements and called for harsh legal sentences. The high youth unemployment rate in Great Britain - one of the highest in Europe - was not mentioned (Cameron 2011).

\footnotetext{
${ }^{6}$ In the government of Prime Minister Blair there was an emphasis on this diagnosis of 'antisocial' or 'dissocial' personality disorder. These diagnoses are controversial in the field. By means of these categories a number of unwanted behaviours were pathologized: vulgarity, threats, disturbing the peace, gangs, vandalism, betting, public drinking, etc. If someone displayed these characteristics they had to reckon with sanctions which were laid out in the 1998 Anti-Social Behaviour Orders.
} 


\section{The culturally inferior - a German peculiarity of the underclass concept}

Paul Nolte, Professor for Recent History at the Free University of Berlin, argues that a new German underclass has arisen that is distinct from other classes. He defines this 'class' by ascribing to its members a uniform and specific 'consumption triangle of tobacco, alcohol and the lottery'. They spend the day with 'lower class television'. Further negative indicators include uncivil and uncivilized behaviour, alienation from education, disinterest in gainful employment, emphasis on comfort and the compulsion to fulfil immediate needs. He argues that the social state, which for the most part transfers social support payments without making them dependent on progress, contributes to the continuance of these behaviours and is therefore counterproductive.

He believes that modern mass culture and the declining 'radiance' of middle-class Leitkultur are at fault for the moral decay and the damaging behaviour of the underclass. The old working class was oriented towards middle class values and thus tried to evolve, while the new 'underclass' has distanced itself from that.

Nolte (2004) intervened in the German social political discussions and brought arguments in favour of his conception of the 'new underclass'. He appealed to the middle class in order to win them over to the cause of (pedagogically) intervening in the culture of poverty. This portrayed them as in possession of better values and behaviour than members of the 'underclass', which made them open to resentment of the poor. His appeal not to let up their efforts and to remember values of the Leitkultur had the effect of ensuring they would not express solidarity with the 'underclass'. This appeal to the middle class shows Nolte's distinct German expression of the underclass debate, which contrasts with its course in the US or Great Britain. It is a clever attempt to create division, and it continues to be effective (Nolte 2004).

Journalists express arguments similar to Nolte's. It is worth noting that the stigmatized 'underclass' concept, which originated from radical 
conservatives in the USA, has found a place in Germany in social work and counselling (see for example Gehrmann and Müller 2010).

\section{Conclusion}

The discourse of the 'underclass' in the USA, Great Britain and Germany is related. Each offers the same explanation about the causes of poverty and social inequality: the poor, marginalized or excluded people are themselves the agents of poverty. The causes lie in their deficient personality structures and shameful behaviour. Social and economic conditions for the emergence and continuance of poverty are thus denied. In all three countries a similar cycle of this 'underclass' discourse arises: an increase in media reports when government social policies are up for debate.

The definitions of the underclass that are shown here seek to discredit the language of class that is founded in socioeconomic factors. They displace questions about social inequality and exploitation and are formulated not to reveal power structures, but rather to obscure them.

\section{References:}

Andreß, Hans-Jürgen (ed.). 1998. Empirical Poverty Research in a Comparative Perspective. Aldershot: Avebury.

Auletta, Ken. 1981a. "A Reporter at Large I. The underclass." New Yorker, November 16. Accessed April 28, 2013, http:/ / www.newyorker.com /archive/1981/11/16/1981_11_16_063_TNY_CARDS_000334768.

Auletta, Ken. 1981b. "A Reporter at Large II. The underclass." New Yorker, November 23. Accessed April 28, 2013, http:/ / www.newyorker.com /archive/1981/11/23/1981_11_23_072_TNY_CARDS_000334871.

Auletta, Ken. 1981c. "A Reporter at Large III. The underclass." New Yorker, November 30. Accessed December 23, 2012, http://www.newyorker.com/archive/1981/11/30/1981_11_30_101_ TNY_CARDS_000336849.

Auletta, Ken. 1982. The Underclass. New York: Random House.

Banfield, Edward C. 1974 [1968]. The Unheavenly City Revisited: A Revision of the Unheavenly City. Boston: Little, Brown \& Co. 
Bourdieu, Pierre and Loïc Wacquant. 2001. "Neoliberal newspeak: notes on the new planetary vulgate." Radical Philosophy 105: 2-5.

Brenner, Robert. 2006. The Economics of Global Turbulence: The Advanced Capitalist Economies from Long Boom to Long Downturn, 1945-2005. London and New York: Verso.

Cameron, David. 2011. London riots: David Cameron's speech in full. Published on August 9. Accessed December 29, 2012, http://www.scotsman. com/news/london-riots-david-cameron-s-speech-in-full-1-1794077.

Gans, Herbert J. 1995. The War against the poor. The underclass and antipoverty policy. New York: Basic Books.

Gehrmann Gerd and Klaus D. Müller. 2010. Aktivierende Soziale Arbeit mit nicht-motivierten Klienten. Mit Arbeitshilfen für Ausbildung und Praxis (Third Edition). Berlin: Walhalla Fachverlag.

Kronauer, Martin 2010. Exklusion. Die Gefährdung des Sozialen im hoch entwickelten Kapitalismus. Frankfurt: Campus.

MacDonald, Robert. 1997. Youth, the 'underclass' and social exclusion. London: Routledge.

Murray, Charles A. 1984. Losing Ground: American Social Policy 1950-1980. New York: Basic Books.

Murray, Charles A. 1990. The Emerging British Underclass. London: Institute of Economic Affairs Health and Welfare Unit. Accessed December 27, 2012. http://www.civitas.org.uk/pdf/cw33.pdf

Murray, Charles A. 1994. Underclass: The Crisis Deepens. London: Institute of Economic Affairs Health and Welfare Unit. Accessed December 27, 2012. http:/ / www.civitas.org.uk/pdf/cw33.pdf

Murray, Charles A. 2012. Coming Apart: The State of White America, 1960-2010. New York: The Crown Publishing Group.

Myrdal, Gunnar. 1962. Challenge to Affluence. New York: Pantheon Books.

Nolte, Paul. 2004. Generation Reform. Jenseits der blockierten Republik. München: C.H. Beck.

Office of Policy Planning and Research, United States Department of Labor. 1965. The Negro Family: The Case For National Action. Accessed 22, December, 2012, http://www.dol.gov/oasam/programs/history/ webid-meynihan.htm\#.UOiTLXnCB-Q.

Paugam, Serge. 1994. La disqualification sociale. Essai sur la nouvelle pauvreté. Paris: Presses Universitaires de France.

Projekt Ideologie Theorie (PIT). 1979. Theorien über Ideologie. Argument Sonderband AS 40. Berlin: Argument Verlag.

Wacquant, Loïc. 1996. "L'Underclass urbaine dans l'imaginaire social et scientique américain." In L'Exclusion: l'état des savoirs, edited by Serge 
Paugam, 248-262. Paris: Editions La Découverte.

Wacquant, Loïc. 2004. "Decivilizing and demonizing: the remaking of the black America ghetto." In The Sociology of Norbert Elias, edited by Steven Loyal and Stephen Quilley, 95-121. Cambridge: Cambridge University Press. 